\title{
Biomonitoring and Inter-Annual Variation of Soil Mite (Acari) Diversity and Community Structure in Lamto Guinean Savannah (Côte d'Ivoire) Submitted to Different Fire Regimes
}

\author{
Julien K. N'Dri ${ }^{1 *}$, Kanvaly Dosso ${ }^{1}$, Aya B. N'Dri ${ }^{1}$, Rodolphe Arnaud G. N'Da ${ }^{1}$, Mouhamadou Kone ${ }^{2}$, N'Golo A. \\ Kone ${ }^{1}$, Fabrice A. Seka ${ }^{1}$, Pacôme K. Pokou ${ }^{1}$ \\ ${ }^{1}$ UFR des Sciences de la Nature, Université Nangui Abrogoua, 02 BP 801 Abidjan 02, Côte d'Ivoire \\ ndri_jk@yahoo.fr, dossokan_sn@una.edu.ci,ndri.brigitte@yahoo.fr, guyarnaud10@gmail.com, \\ ngolo197804@yahoo.fr, a.fabriceseka@gmail.com, ebouop38@gmail.com \\ 2Université Peleforo Gon Coulibaly, Côte d'Ivoire \\ kmouhamadou2@yahoo.fr
}

\begin{abstract}
The objective of the study conducted in the Lamto Guinean savannah situated at $165 \mathrm{~km}$ northwest of Abidjan, Côte d'Ivoire consisted to assess the changes in soil mite abundance, diversity and community structure specific to the second fire cycle applied in 2015, as well as the inter-annual variation between the two fire cycles (2014 and 2015). Three study sites (Salty marigot, Plateau and North piste) were selected in shrub savannah, where on each, three adjacent stands of $100 \mathrm{~m} \times 50 \mathrm{~m}$ formerly delimited were considered. The three fire regimes (early, mid-season, and late fire) were respectively applied on the three sites and stands. Thus, 135 soil cores ( 5 soil cores $\times 3$ sampling periods $\times 3$ fire regimes or stands $\times 3$ sites) were used for mite extraction. 108 soil cores were taken at two upper layers $(0-5$ and $5-10 \mathrm{~cm})$ for determination of the bulk density and water content. Whatever the fire regimes, the mean density of soil mites decreased after the fire application. The highest value of density was observed through the early fire $\left(1,715 \pm 327\right.$ ind. $\left.\mathrm{m}^{-2}\right)$ whereas the lowest value was recorded during the mid season fire $\left(1,433 \pm 153\right.$ ind. $\left.\mathrm{m}^{-2}\right) .41$ species had been recorded along the three fire regimes and distributed as follows: early fire 34 species, mid season fire 20 species, and late fire 13 species. The mean species richness of soil mites changed significantly across the fire regimes, and reduced after the fire application, except for the mid season fire. The Simpson diversity index was significantly modified across the fire regimes, and increased after the fire application. Beyond to 24 specialist species, over $50 \%$ of the species observed before the burns were rediscovery after the fire application, and could explain this variation. The inter-annual variation of soil mites showed that the density (early fire, mid season fire, and late fire), mite richness (early fire), and diversity (early fire and late fire) increased whereas the mite richness (mid season fire and late fire), and diversity (mid season fire) decreased, respectively, during 2015-burn compared to the previous cycle (2014-burn). The rebound of soil mite parameters during the second fire cycle could be assigned (i) to litter and woody debris, which burn in a mosaic, reflecting local fire intensity, (ii) improving of stand complexity and canopy structure, and (iii) fire tolerance of mites.
\end{abstract}

Keywords: Lamto Savannah, Soil Mite Abundance, Diversity and Community Structure, Fire Regimes and Fire Cycles, Inter-Annual Variation

Academic Discipline and Sub-Disciplines: Ecology-Ecosystem-Biodiversity

Type (Method/Approach): Prescribed fire and biomonitoring

Language: English

Date of Submission: 06/02/2018

Date of Acceptance: 20/02/2018

Date of Publication: 15/03/2018

ISSN: 2393-9257

Volume: 05 Issue: 01

Journal: Journal of Advances in Natural Sciences

Publisher: CIRWORLD

Website: https://cirworld.com

This work is licensed under a Creative Commons Attribution 4.0 International License. 


\section{Introduction}

The savannahs, defined broadly as tropical and subtropical grasslands (characterized by grasses with C4 photosynthetic pathway) with varying densities of tree cover, constitute the most fire-prone ecosystems on Earth (Russell-Smith et al., 2013). In protected areas, savannah managers are returning repetitive fire to the landscape to facilitate regeneration of desirable species. Generally, fire is seen as important management tool and biodiversity conservation (Driscoll et al., 2010; Hugo-Coetzee and Avenant, 2011). Its use and its various applications favor landscape heterogeneity, namely diversification of vegetation and soil biodiversity (Hudak et al., 2004). Early theories focused on climatic controls, but a conceptual model has emerged suggesting that savanna trees are subject to a fire-mediated recruitment bottleneck, with frequent fires preventing recruitment of saplings into the tree layer and maintaining biomass well below its climate-determined upper bound (Murphy et al., 2015). However, the removal of the litter dwelling represents a substantial loss of habitat for most soil mesofauna. Even if the response of the disturbance depends on the frequency, duration, size or spatial extent, and their intensity or severity (Bengtsson, 2002), several studies have pointed out that the responses of soil microarthropods to fire vary depending on the type of ecosystem and range from a large reduction in species richness and abundance (Kim and Jung, 2008; Camann et al., 2008, 2012). In addition to microarthropods, fires affect also soil properties by decreasing the soil organic carbon (Certini et al., 2011). Such carbon losses are attributable to the almost complete elimination of the litter layer. According to Kim and Jung (2008), burning out of leaf litter and other organic matter may cause the depletion of food source of soil arthropods since most of the soil microarthropods are decomposers of organic materials. Soil mites play a key role in the ecological functioning of soil. They are involved in litter fragmentation, organic matter decomposition, and minerals recycling (Gulvik, 2007; Yang and Chen, 2009), and therefore are seen as good indicators of the ecological quality of the soil (Zhao et al., 2013). Indeed, the abundance, diversity and community structure of free-living mites (Acari) respond considerably to land management practiced (BehanPelletier, 1999; Camann et al., 2012). The distribution and abundance of these biological components change in time and space because of variable and dynamic interactions among the biotic and abiotic components (Kim and Jung, 2008). The prescribed fire alters oribatid assemblages, reducing species richness and species diversity and modifying assemblage dominance relationships as observed by Camann et al. (2008, 2012). Most of the studies based on short term effects are devoted to forest ecosystems. Also, no investigation has been made to understand the recovery process after the fire in relation to the resilience after disturbance (Kim and Jung, 2013).

With an area of 2,500 ha, the Lamto savannah is one of the most protected areas. The management of this ecosystem includes the use of prescribed fire. Traditionally, the mid season fire was practiced in Lamto savannah each year for over 30 years. This fire is applied to relatively dry vegetation towards mid January. However, it must be noted that regularly burned patches tend to become afforested. For this reason, two other types of fire that are the " early fire » and the "late fire» respectively established in November and March are associated to the first one. The impact of these three prescribed fires on soil mite community was evaluated in 2014 during the first fire cycle (N'Dri et al., 2017). According to authors, 70 species were observed, with 29, 44 and 31 species recorded respectively during the early, mid-season and late fires. Mite density and species richness significantly varied among the three fire regimes and decreased substantially after each fire application. Except for the mid-season fire, the Simpson index from all mites significantly differed across sampling periods. Lower Oribatida represented $25 \%$ of the total Oribatida. Whatever the fire regime, brachypyline Oribatida abundance increased the day after fire application. Overall, fire intensity reduced drastically soil mite abundance and diversity. In 2015, the second fire cycle was applied. The aim of the present investigation consisted to assess the changes in soil mite abundance, diversity and community structure specific to the second fire cycle applied in 2015, as well as the inter-annual variation between the two fire cycles (2014 and 2015). We hypothesized that (i) whatever the fire regime, soil mite density and diversity decrease after the application of fire, (ii) soil mite density and community diversity reduce during the second fire cycle compared to the first one. 


\section{Materials and Methods}

\subsection{Site description}

This study was carried out in Lamto Guinean savannah $\left(6^{\circ} 13^{\prime} \mathrm{N}, 5^{\circ} 02^{\prime} \mathrm{W}\right)$ located at $165 \mathrm{~km}$ northwest of Abidjan. The climate is intertropical type with four seasons - a long dry season from December to February, a long-wet season from March to July, a short dry season in August, and a short-wet season from September to November. Annual rainfall during the study year (2014-2015) was about 1,235 mm, and the average monthly temperature was about $29^{\circ} \mathrm{C}$. The vegetation of Lamto is a forest-savannah mosaic (Menaut and César, 1979), characterized by (i) the gallery forests that borders the Bandama River, and the islets of forest which are surrounded by savannahs, (ii) herbaceous savannahs dominated by Loudetia simplex, (iii) shrub savannahs dominated by Hyparrhenia diplanda and Andropogon sp., (iv) wooded savannahs, (v) and shrub savannahs protected from fire. Soils are ferralitic type under forests and tropical ferruginous type under savannah (Riou, 1974).

\subsection{Sampling design and mite identification}

The field works were conducted in shrub savannah of Lamto not protected from fire. In this zone, three sites (Salty marigot, Plateau and North piste) were selected and considered as replications. The site of Plateau was more wooded whereas Salty marigot and North piste were grassy. The choice of these sites allowed taking into account the vegetation heterogeneity. On each site, three adjacent stands of $100 \mathrm{~m} \times 50 \mathrm{~m}$ were delimited for the sampling. A layer of $10 \mathrm{~m}$ width was made around each plot. Five sampling points were allocated on each stand following the two diagonals. The three fire regimes were applied respectively on the three stands and the three sites. The "early fire" was applied in November to humid vegetation with a green appearance, the "mid season fire" in January to relatively dry vegetation, and the "late fire" in March to highly dry vegetation. At each fire regime, soil cores were taken three days before the fire application (BE), the day after the fire application (AF) and one month after the fire application (OM). On each stand, five soil cores including litter thickness was randomly taken with a steel corer $(\varnothing 4 \mathrm{~cm})$ at $0-10 \mathrm{~cm}$ soil depth. Thus, 5 soil cores $\times 3$ sampling periods $\times 3$ fire regimes or stands $\times 3$ sites gave a total of 135 soil cores. These soil cores were brought to the laboratory in plastic packets for mite extraction. Fire intensity data were provided by Soro (2016). Three days before the fire application, three soil cores were taken following the 0-5 and 5-10 cm layers on the first diagonal by using the cylinder method (Assié et al., 2008) for physical measurements. One month after the application of the fire, these same soil cores were performed on the opposite diagonal. A total of 108 soil cores were taken for estimation of the bulk density and water content.

Mites were extracted from soil using modified Berlese-Tullgren funnel with heat applied over the course of 10 days and collected into $70 \%$ ethanol before determination. All mites from samples were mounted on cavity slides containing $85 \%$ lactic acid solution and observed with a digital camera VC.5000 mounted on a NOVEX light microscope. In the absence of African keys, adult mites were identified to major groups (Actinedida, Gamasida, and Oribatida), family, genus and morphospecies levels by using keys and illustrations provided in Balogh and Balogh (1992), Krantz and Walter (2009) and Walter et al. (2013).

\subsection{Data analysis}

Soil mite abundance was expressed as the mean number of individuals per square meter. The diversity of communities was studied by calculating the mean species richness, cumulative species richness, Simpson index, Simpson diversity index, evenness, Berger Parker index, and the Jaccard dissimilarity index expressed in percentages. The community structure was characterized by using dominant, ubiquitous, and specialist species (Badejo and Ola-Adams, 2000). The relative dominance of each species was classified according to Yang et al. (2015): Eudominant: species comprising over $30 \%$ of the total number of individuals, Dominant: $10-30 \%$ of individuals, Sub-dominant: $5-10 \%$ of individuals, Minor: $1-5 \%$ of individuals, and Rare: less than $1 \%$ of the total number. A particular interest was devoted to Gamasid and Oribatid mites due to their abundance and 
their key role in the ecosystem functioning. Soil bulk density was estimated using the cylinder method (Assié et al., 2008). Soil water content was determined after drying at $105^{\circ} \mathrm{C}$ for $48 \mathrm{~h}$.

The homogeneity of variances was analyzed using the Levene test. Numerical data prior to the statistical analysis were subjected to logarithmic transformation - $\log (x+1)$ because the data did not follow a normal distribution (Gérard and Berthet, 1966). A one-way ANOVA associated with the post-hoc Tukey's test was performed to examine the effects of fire regimes and sampling periods on the soil biological and physical characteristics. The Bulk density and water content were also evaluated following soil depth using the Student t-test. The factorial Anova added to general linear mixed (GLM) model were used to explore the interaction fire regimes $x$ sampling period's effects on soil biological and physical characteristics. The inter-annual variation of soil biological and physical characteristics was analyzed by using the Student t-test. All tests were carried out using the software Statistica 7.1. (StatSoft Inc., Tulsa, USA). Unweighted Pair-Group Method using arithmetic Averages (UPGMA) was used as the clustering method (Thioulouse et al. 1997). The cumulative species richness was estimated after 500 randomizations by using the software EstimateS 7.5. The first-order jackknife non-parametric estimator was used to estimate the true species richness. We used rarefaction to determine whether observed differences in species richness were attributable to sample size differences.

\section{Results}

\subsection{Soil mite density}

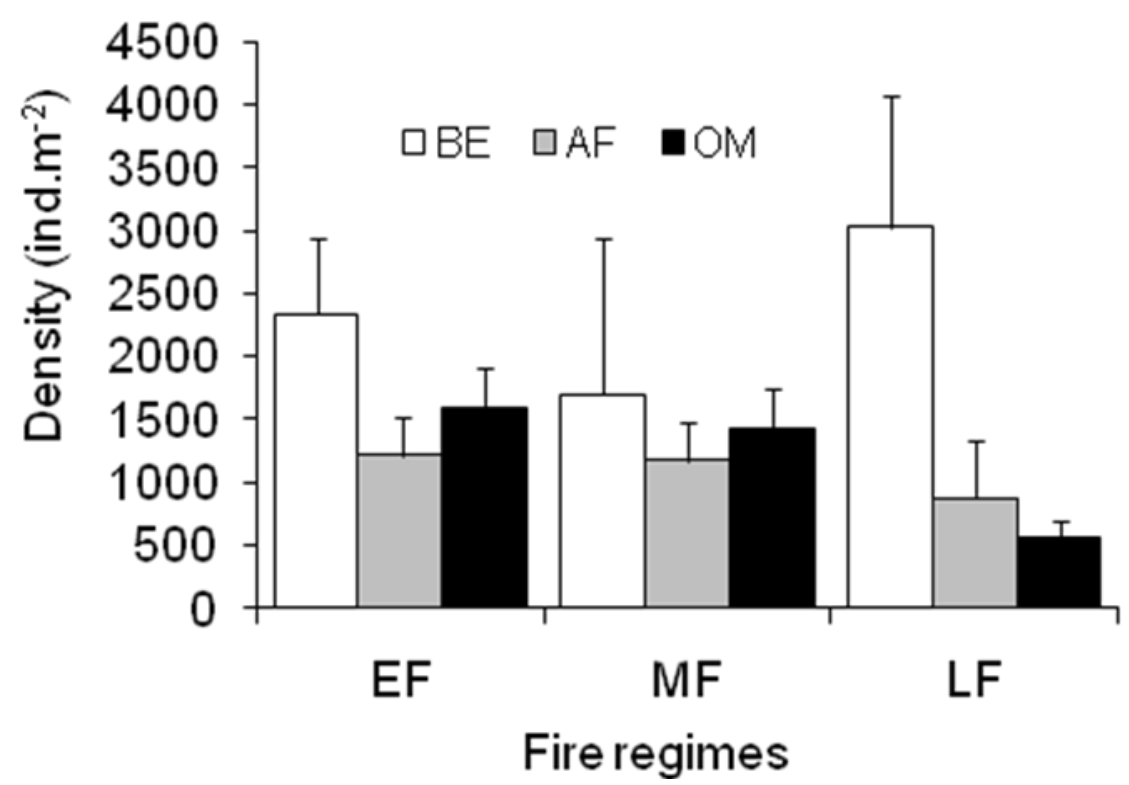

Figure 1: Soil mite abundance recorded along the fire regimes and the sampling periods. EF-Early Fire, MFMid season Fire, LF-Late Fire, BE-Before fire, AF-After Fire, OM-One Month later.

The mean density of soil mites did not differ significantly across the fire regimes (one-way ANOVA; $F=1.91, p$ $=0.151)$ during the second cycle. The highest value of density was observed through the early fire $(1,715 \pm$ 327 ind. $\left.\mathrm{m}^{-2}\right)$ whereas the lowest value was recorded during the mid season fire $\left(1,433 \pm 153\right.$ ind. $\left.\mathrm{m}^{-2}\right)$. Whatever the fire regimes, the mean density of soil mites did not vary significantly on the three sampling periods: early fire (one-way ANOVA; $F=0.72, p=0.490$ ), mid season fire (one-way ANOVA; $F=1.95, p=$ 0.153 ), and late fire (one-way ANOVA; $F=2.37, p=0.105$ ). In all cases, highest densities (Figure 1 ) were recorded before the fire application (early fire: $2,335 \pm 614$ ind. $\mathrm{m}^{-2}$, mid season fire: 1,698 \pm 1250 ind. $\mathrm{m}^{-2}$, and late fire: $3,025 \pm 1049$ ind. $\mathrm{m}^{-2}$ ). The density of soil mites did not vary significantly with the fire regimessampling periods interaction (GLM; $F=1.72, p=0.149$ ). During the first cycle of fire, the density of soil mites was lower for the late fire and higher for the mid season fire. Whatever the fire regimes, the density of soil 
mites increased in the second cycle compared to the first fire cycle. However, this inter-annual variation of the mite density was significant during the early (t-test; $t=-2.72, p=0.007$ ) and late (t-test; $t=-2.26, p=0.026$ ) fire. While considering the sampling periods, the inter-annual variation of the density highlighted that the soil mites increased significantly one month after the early fire (t-test; $t=-4.24, p=0.0002$ ) and before the late fire (t-test; $t=-2.30, p=0.028)$, respectively, in the second fire cycle compared to the first one.

\subsection{Species richness and diversity of soil mites}

The mean species richness of soil mites changed significantly (Anova $1 ; F=9.84, p=0.0001$ ) across the fire regimes, and decreased after the fire application, except for the mid season fire. The species richness of soil mites did not differ significantly with the fire regimes-sampling periods interaction (GLM; $F=1.57, p=0.183)$. The mean species richness observed during the first cycle of fire significantly varied across the three fire regimes and sampling periods. In total, the soil mite richness reduced during the second cycle (41 species) compared to the previous one. The soil mite richness slightly decreased during the mid season fire (t-test; $t=$ $0.786, p=0.433$ ), and the late fire (t-test; $t=-0.395, p=0.693$ ), and significantly increased during the early fire (t-test; $t=-2.057, p=0.042$ ), respectively, in the second cycle compared to the first fire cycle. While considering the sampling periods, the inter-annual variation indicated that the species richness was significantly higher one month after the early fire (t-test; $t=-3.456, p=0.001$ ), and significantly lower before the mid season fire (t-test; $t=2.687, p=0.011$ ), respectively, in the second fire cycle compared to the first one.

The Simpson index significantly varied across the three fire regimes (one-way ANOVA; $F=5.38, p=0.005$ ) during the second cycle of fire (Table 1). Apart from the early fire (one-way ANOVA; $F=0.27, p=0.758$ ), and the late fire (one-way ANOVA; $F=1.07, p=0.350$ ), the Simpson index significantly varied through the sampling periods during the mid season fire (one-way ANOVA; $F=3.47, p=0.04$ ). Its highest values were recorded one month after the early $(0.42 \pm 0.10)$, and the mid season $(0.74 \pm 0.09)$ fires and before the late fire $(0.32 \pm 0.11)$ application. The Simpson index did not change significantly with the fire regimes-sampling periods interaction (GLM; $F=1.38, p=0.242)$.

The Simpson diversity index significantly (one-way ANOVA; $F=5.38, p=0.005$ ) differed across the fire regimes during the second cycle, and increased after fire application. Contrary to the early fire (one-way ANOVA; $F=0.27, p=0.758$ ), and the late fire (one-way ANOVA; $F=1.07, p=0.350$ ); the values of Simpson diversity index varied significantly through sampling periods for the mid season fire (one-way ANOVA; $F$ $=3.47, p=0.040$ ). However, it did not vary significantly with the fire regimes-sampling periods interaction $(\mathrm{GLM} ; F=1.38, p=0.242)$. The inter-annual variation revealed an increase of the Simpson diversity index for the early fire ( $\mathrm{t}$-test; $t=-0.610, p=0.542$ ), late fire ( $\mathrm{t}$-test; $t=-1.734, p=0.863$ ), and a decrease for the mid season fire (t-test; $t=-0.898, p=0.376$ ) during the second cycle compared to the first cycle. While considering the sampling periods, the inter-annual variation showed that the Simpson diversity index significantly increased before the early fire (t-test; $t=-2.891, p=0.007$ ), and significantly decreased one month after the mid season fire (t-test; $t=4.379, p=0.0001$ ) during the second cycle compared to the first one. During the second cycle of fire, the evenness did not vary significantly across fire regimes (one-way ANOVA; $F=0.88, p=$ 0.414 ) and sampling periods: early fire (one-way ANOVA; $F=0.55, p=0.579$ ), mid season fire (one-way ANOVA; $F=0.88, p=0.420$ ), and late fire (one-way ANOVA; $F=0.57, p=0.567$ ).

\subsection{Community structure}

The soil mite community consisted of three major groups (Oribatida, Gamasida, and Actinedida). Whatever the fire regimes, the Oribatid mites (73-80\%) and Gamasid mites (15-27\%) represented the dominant groups. The soil mite community was constituted of 41 morphospecies. Respectively 34,20 , and 13 soil mite species were collected during the early, mid season, and late fires. 17 ubiquitous species and 24 specialist species were observed across the three fire regimes (see appendix). Successively 0,1 , and 1 eudominant species; 0,1 , and 1 dominant species; 4, 3, and 2 sub-dominant species and 30, 15, and 9 minor species were recorded during the early, mid season and late fires. Rare species were not found in the biological material. Over $50 \%$ of the observed species before the fire application were rediscovered respectively after the application of each fire 
Table 1: Soil mite diversity parameters estimated along the fire regimes and sampling periods. BE-Before fire, AF-After fire, OM-One month later. Smean: Average number of mite species, D: Simpson index, 1-D: Simpson diversity index, J': Evenness

\begin{tabular}{|c|c|c|c|c|c|c|}
\hline \multirow[b]{3}{*}{$S_{\text {mean }}$} & \multicolumn{5}{|c|}{ Early fire } & \multirow{3}{*}{$\begin{array}{c}P \text {-value } \\
0.189^{\text {ns }}\end{array}$} \\
\hline & \multicolumn{2}{|r|}{$\mathrm{BE}$} & \multicolumn{2}{|c|}{$\mathrm{AF}$} & OM & \\
\hline & 2.33 & $\pm 0.58^{\mathrm{a}}$ & 1.13 & $\pm 0.33^{a}$ & $1.80 \pm 0.41^{\mathrm{a}}$ & \\
\hline D & 0.34 & $\pm 0.08^{\mathrm{a}}$ & 0.33 & $\pm 0.10^{\mathrm{a}}$ & $0.42 \pm 0.10^{\mathrm{a}}$ & $0.758^{\text {ns }}$ \\
\hline $1-D$ & 0.65 & $\pm 0.08^{\mathrm{a}}$ & 0.66 & $\pm 0.10^{\mathrm{a}}$ & $0.57 \pm 0.10^{\mathrm{a}}$ & $0.758^{\text {ns }}$ \\
\hline$J^{\prime}$ & 0.34 & $\pm 0.10^{a}$ & 0.21 & $\pm 0.08^{a}$ & $0.25 \pm 0.09^{a}$ & $0.579^{\text {ns }}$ \\
\hline
\end{tabular}

\begin{tabular}{|c|c|c|c|c|c|}
\hline \multirow[b]{3}{*}{ Smean } & \multicolumn{4}{|c|}{ Mid season fire } & \multirow{3}{*}{$\begin{array}{c}P \text {-value } \\
0.224^{\text {ns }}\end{array}$} \\
\hline & \multicolumn{2}{|r|}{$\mathrm{BE}$} & AF & OM & \\
\hline & 0.60 & $\pm 0.21^{a}$ & $1.00 \pm 0.30^{\mathrm{a}}$ & $1.20 \pm 0.20^{a}$ & \\
\hline D & 0.38 & $\pm 0.12^{\mathrm{a}}$ & $0.36 \pm 0.11^{\mathrm{a}}$ & $0.74 \pm 0.09^{b}$ & $0.040^{*}$ \\
\hline $1-D$ & 0.61 & $\pm 0.12^{\mathrm{a}}$ & $0.63 \pm 0.11^{a}$ & $0.26 \pm 0.09^{b}$ & $0.040^{*}$ \\
\hline \multirow[t]{3}{*}{$J^{\prime}$} & 0.08 & $\pm 0.08^{a}$ & $0.17 \pm 0.08^{a}$ & $0.26 \pm 0.12^{a}$ & $0.420^{\mathrm{ns}}$ \\
\hline & \multicolumn{4}{|c|}{ Late fire } & \\
\hline & \multicolumn{2}{|r|}{$\mathrm{BE}$} & $\overline{A F}$ & OM & $P$-value \\
\hline$S_{\text {mean }}$ & 0.66 & $\pm 0.25^{a}$ & $0.40 \pm 0.23^{a}$ & $0.66 \pm 0.23^{a}$ & $0.665^{\mathrm{ns}}$ \\
\hline D & 0.31 & $\pm 0.11^{a}$ & $0.12 \pm 0.07^{a}$ & $0.23 \pm 0.08^{a}$ & $0.350^{\text {ns }}$ \\
\hline $1-D$ & 0.68 & $\pm 0.11^{a}$ & $0.87 \pm 0.07^{a}$ & $0.76 \pm 0.08^{a}$ & $0.350^{\text {ns }}$ \\
\hline$J^{\prime}$ & 0.20 & $\pm 0.11^{a}$ & $0.11 \pm 0.07^{a}$ & $0.26 \pm 0.11^{a}$ & $0.567^{\mathrm{ns}}$ \\
\hline
\end{tabular}

$$
{ }^{*} P<0.05
$$

regime. 10 species of Gamasida and 29 species of Oribatida were observed along the fire regimes. 8, 2, and 2 species of Gamasida and 25, 16, and 10 species of Oribatida were respectively recorded during the early, mid season and late fires. The community of Gamasida was composed of two groups (Gamasina and Uropodina). The abundance of Gamasina (one-way ANOVA; $F=2.92, p=0.049$ ) and Uropodina (one-way ANOVA; $F$ $=3.80, p=0.024)$ mites significantly varied through the fire regimes. The highest abundances of Gamasina $(9$ \pm 2 individuals), and Uropodina (12 \pm 1.52 individuals) were both recorded during the early fire (Figure 2A). The community of Oribatida was constituted of five groups (Palaeosomata, Parhyposomata, Mixonomata, Desmonomata and Brachypylina). Contrary to Parhyposomata (one-way ANOVA; $F=0.50, p=0.607$ ), Palaeosomata (one-way ANOVA; $F=0.51, p=0.598$ ), Mixonomata (one-way ANOVA; $F=2.04, p=0.133$ ) and Brachypylina (one-way ANOVA; $F=0.12, p=0.879$ ), only the abundance of Desmonomata (one-way ANOVA; $F=4.90, p=0.008)$ significantly varied across the fire regimes. The highest abundances of Palaeosomata $(3 \pm$ 
0.57 individuals), Parhyposomata ( $1 \pm 0.33$ individuals), Mixonomata ( $2 \pm 0.66$ individuals) and Desmonomata (11 \pm 1.45 individuals) were found during the early fire whereas those of Brachypylina $(63 \pm 9.5$ individuals) were recorded during the late fire (Figure 2B). Whatever the fire regime, the higher Oribatida constituted the dominant group (over $75 \%$ of the Oribatid mites). Values of the Jaccard dissimilarity index estimated between fire regimes were above $60 \%$.
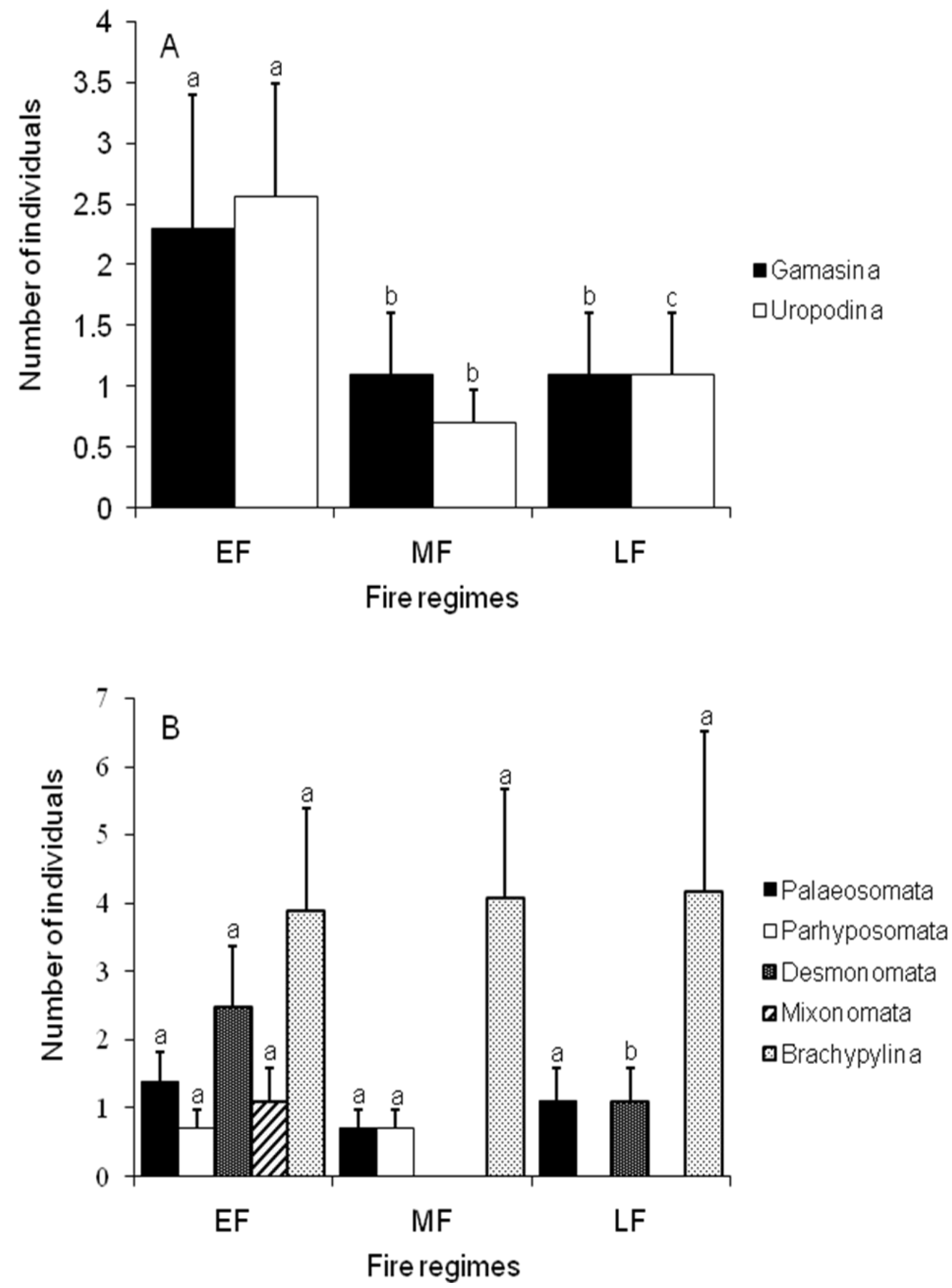

Figure 2: Abundance logarithmic transformation - In $(x+1)$ of Gamasida (A) and Oribatida (B) major groups across the fire regimes. EF-Early fire, MF-Mid season fire, LF-Late fire.

While considering the sampling periods, the hierarchical classification of soil mite communities showed five groups (Figure 3). The clustering was as follows: first group (One month after the early fire), second (Before, 
After, and One month after the late fire), third (After and One month after the mid season fire), fourth (Before the mid season fire and After the early fire), and the fifth group (Before the early fire). The cumulative species richness could reach respectively 47,30, and 13 species and would represent successively 73,67 , and 100\% of the expected species during the early, mid season and late fires. The rarefaction data was lower during the late fire relative to early fire and mid season fire (Figure 4). However, these rarefaction curves did not reach an asymptote except for the late fire, indicating that the sampling effort was not sufficient to complete the mite species inventories.

Figure 3: Hierarchical classification of fire regimes and sampling periods based on mite species composition using UPGMA (Unweighted Pair-Group Method using Arithmetic averages). BEEF: Before the early fire, AF-EF: After the early fire, OM-EF: One month after the early fire, BE-MF: Before the mid season fire, AF-MF: After the mid season fire, OM-MF: One month after the mid season fire, BE-LF: Before the late fire, AF-LF: After the late fire, OM-LF: One month after the late fire.
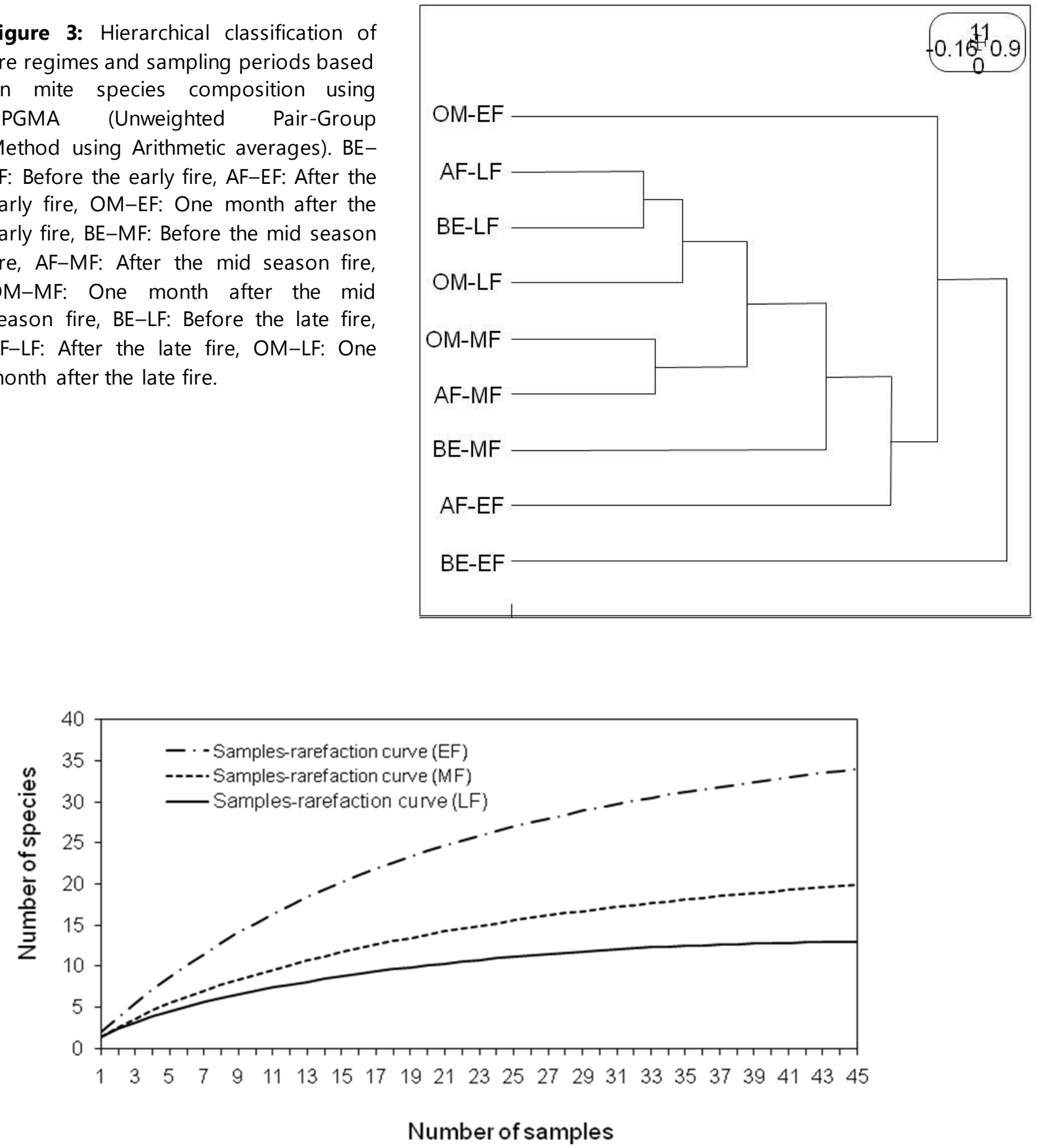

Figure 4: Sample-based rarefaction curves of species richness from the three fire regimes. The $95 \%$ confidence intervals are not shown. EF-Early Fire, MF-Mid season Fire, LF-Late Fire. 


\subsection{Soil physical characteristics}

During the second cycle of fire, the values of bulk density were nearly similar and varied from $0.9 \pm 0.03 \mathrm{~g} \cdot \mathrm{cm}^{-3}$ (5-10 cm, before the late fire application) to $1.38 \pm 0.08 \mathrm{~g} \cdot \mathrm{cm}^{-3}(5-10 \mathrm{~cm}$, one month after the early fire application). Whatever the layer and the sampling periods, the values of bulk density significantly differed through the fire regimes, successively, before $(0-5 \mathrm{~cm}$ : one-way ANOVA, $F=12.26, p=0.0001 ; 5-10 \mathrm{~cm}$ : oneway ANOVA, $F=13.01, p=0.0001)$, and one month after the fire application $(0-5 \mathrm{~cm}$ : one-way ANOVA, $F=$ $10.02, p=0.0006 ; 5-10 \mathrm{~cm}$ : one-way ANOVA, $F=6.31, p=0.0062)$. It decreased significantly with soil depth (ttest; $t=3.303, p=0.010$ ) before the application of the late fire (Table 2). The reverse trend was measured one month after the application of the late fire ( $\mathrm{t}$-test; $t=-3.128, p=0.014)$. The bulk density significantly changed with the fire regimes-sampling periods interaction. The inter-annual variation of the bulk density was significant before the mid season (t-test; $t=-6.88, p=0.000004$ ), and late (t-test; $t=4.83, p=0.0001$ ) fires, and one month after the early (t-test; $t=-4.11, p=0.0008$ ) and mid season (t-test; $t=-2.21, p=0.041$ ) fires.

Table 2: Soil physical Characteristics following the fire regimes and the sampling periods. BE-Before fire, OMOne Month later, $\mathrm{n}=9$.

Fire regimes

\begin{tabular}{|c|c|c|c|c|c|}
\hline \multicolumn{2}{|l|}{ Bulk density } & Early fire & Mid season fire & Late fire & $P$-value \\
\hline \multirow[t]{2}{*}{$0-5 \mathrm{~cm}$} & $\mathrm{BE}$ & $1.03 \pm 0.04^{a}$ & $1.31 \pm 0.05^{\mathrm{b}}$ & $1.02 \pm 0.02^{c}$ & $0.0001^{\star \star \star}$ \\
\hline & OM & $1.27 \pm 0.06^{a}$ & $1.36 \pm 0.05^{a}$ & $1.05 \pm 0.01^{\mathrm{b}}$ & $0.0006^{* \star *}$ \\
\hline \multirow[t]{2}{*}{$5-10 \mathrm{~cm}$} & $\mathrm{BE}$ & $1.15 \pm 0.08^{a}$ & $1.34 \pm 0.05^{b}$ & $0.9 \pm 0.03^{c}$ & $0.0001^{* * *}$ \\
\hline & OM & $1.38 \pm 0.08^{a}$ & $1.22 \pm 0.04^{\mathrm{ab}}$ & $1.09 \pm 0.02^{\mathrm{b}}$ & $0.0062^{\star \star}$ \\
\hline $0-5 \mathrm{~cm} / 5-10 \mathrm{~cm}$ & $\mathrm{BE}$ & 0.562 & 0.764 & $0.010^{*}$ & \\
\hline $0-5 \mathrm{~cm} / 5-10 \mathrm{~cm}$ & OM & 0.380 & 0.132 & $0.014^{*}$ & \\
\hline \multicolumn{6}{|l|}{ Water content } \\
\hline \multirow[t]{2}{*}{$0-5 \mathrm{~cm}$} & $\mathrm{BE}$ & $13.3 \pm 0.90^{\mathrm{a}}$ & $1.68 \pm 0.17^{b}$ & $26.32 \pm 0.34^{c}$ & $0.0000001^{* \star \star}$ \\
\hline & OM & $12.99 \pm 1.59^{a}$ & $20.62 \pm 3.84^{\mathrm{a}}$ & $17.88 \pm 2.83^{\mathrm{a}}$ & 0.1923 \\
\hline \multirow[t]{2}{*}{$5-10 \mathrm{~cm}$} & $\mathrm{BE}$ & $15.01 \pm 3.04^{a}$ & $1.88 \pm 0.36^{\mathrm{b}}$ & $25.72 \pm 0.94^{c}$ & $0.0000001^{* \star *}$ \\
\hline & OM & $19.26 \pm 9.89^{a}$ & $22.76 \pm 3.21^{\mathrm{a}}$ & $22.82 \pm 2.72^{\mathrm{a}}$ & 0.8982 \\
\hline $0-5 \mathrm{~cm} / 5-10 \mathrm{~cm}$ & $\mathrm{BE}$ & 0.499 & 0.617 & 0.375 & \\
\hline $0-5 \mathrm{~cm} / 5-10 \mathrm{~cm}$ & $\mathrm{OM}$ & 0.562 & 0.651 & $0.002^{* *}$ & \\
\hline
\end{tabular}

${ }^{\star} P<0.05,{ }^{* *} P<0.01,{ }^{* * \star} P<0.001$

During the second cycle of fire, the value of water content ranged from $1.68 \pm 0.17 \%(0-5 \mathrm{~cm}$, before the mid season fire) to $26.32 \pm 0.34 \%(0-5 \mathrm{~cm}$, before the late fire). Whatever the layer and the sampling periods, the values of water content significantly varied across the fire regimes, respectively, before the fire application $(0-5$ 
cm: one-way ANOVA, $F=47.1, p=0.0000001 ; 5-10 \mathrm{~cm}$ : one-way ANOVA, $F=41.40, p=0.0000001)$. The soil water content significantly increased (t-test; $t=-4.47, p=0.002$ ) with soil depth one month after the application of the late fire. It varied significantly with the fire regimes-sampling periods interaction (Table 3). Except for one month after the early and late fires, the inter-annual variation of soil water content was significant, particularly before the early (t-test; $t=2.19, p=0.043$ ), mid season (t-test; $t=8.58, p=0.00001$ ), and late (t-test; $t=-20.79, p=0.00001$ ) fires, and one month after the mid season fire (t-test; $t=-5.94, p=$ $0.00001)$.

Table 3: Anova table of general linear mixed effect models on log $(x+1)$-transformed soil physical characteristics across Fire regimes and Sampling periods. F-values and the corresponding $P$-values are displayed.

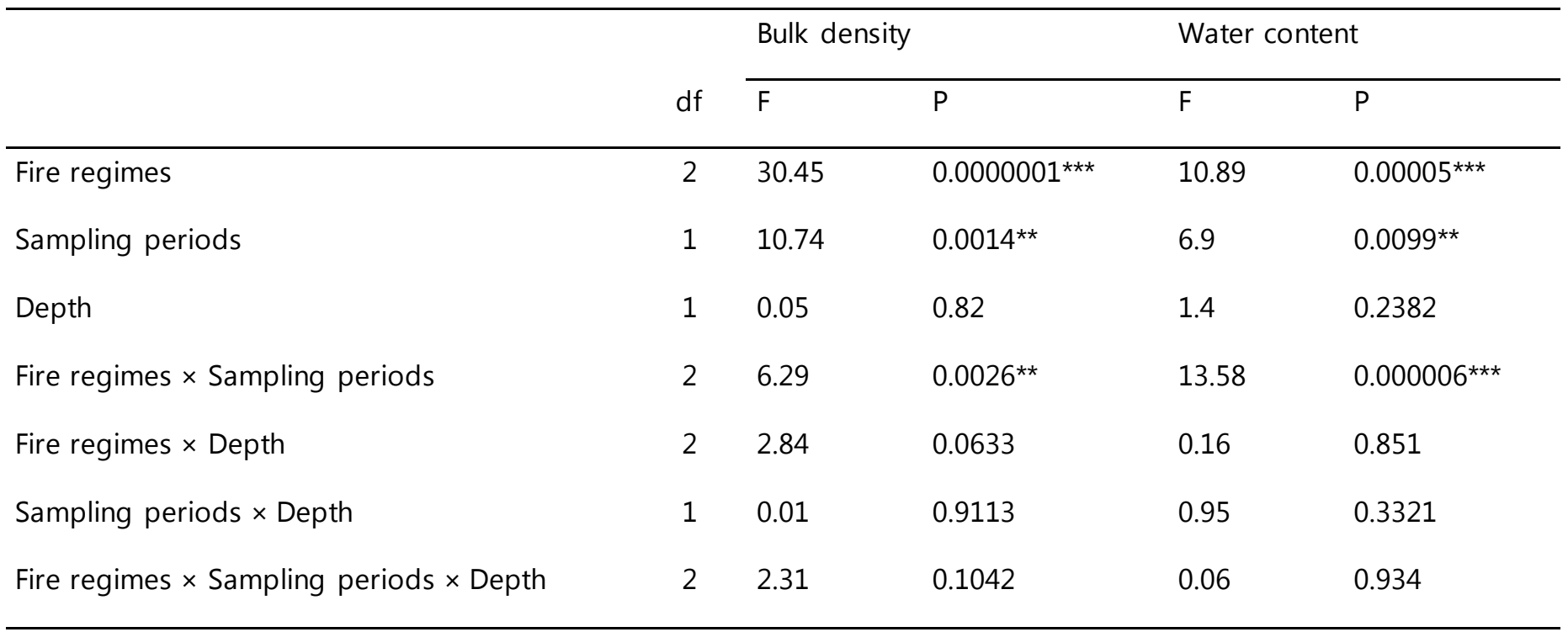

$$
{ }^{* *} P<0.01,{ }^{* * *} P<0.001
$$

\subsection{Relationships between soil physical characteristics and biological parameters}

The density of soil mites was significantly correlated to the bulk density, successively, one month after the early $(R=-0.750, p=0.018)$ and late fires $(R=-0.92, p=0.0004)$, and before the late $(R=-0.74, p=0.022)$ fire (Table 4). The water content was significantly correlated to the density of soil mites, respectively, one month after the mid season $(R=0.734, p=0.024)$ and late $(R=0.785, p=0.012)$ fires. The species richness of soil mites was significantly correlated to the bulk density one month after the early fire $(R=-0.747, p=0.020)$.

\section{Discussion}

Fire is an important variable that causes ecosystem change significantly modifying the structure and functioning of the system (Jung et al., 2010). Its impact on the soil physico-chemical and biological parameters vary depending on the type of habitat. Whatever the type of terrestrial ecosystem, the biological compartment plays an essential role in soil functioning and providing ecosystem services (Coleman et al., 2004). The huge niche partitions in soil associated to the diversity of microhabitats and to spatial and temporal segregation between species promote the maintenance of the biodiversity (Decaëns, 2010). Unfortunately, the prescribed fire reduces the soil mite abundance and diversity, as highlighted by Camann et al. (2008, 2012). These observations are similar to the results of our investigation. On the three fire regimes, the soil mite density 
Table 4: Spearman correlation between biological variables and soil physical characteristics

\begin{tabular}{|c|c|c|c|c|c|c|c|c|}
\hline & \multicolumn{4}{|c|}{ Mite density } & \multicolumn{4}{|c|}{ Species richness } \\
\hline & \multicolumn{2}{|c|}{ Before fire } & \multicolumn{2}{|c|}{ One month later } & \multicolumn{2}{|c|}{ Before fire } & \multicolumn{2}{|c|}{ One month later } \\
\hline & $R$ & $p$-value & $R$ & $p$-value & $R$ & $p$-value & $R$ & $p$-value \\
\hline \multicolumn{9}{|l|}{ Bulk density } \\
\hline Early fire & -0.089 & 0.818 & -0.754 & $0.018^{*}$ & 0.015 & 0.748 & -0.747 & $0.020^{*}$ \\
\hline Mid season fire & -0.289 & 0.450 & -0.393 & 0.294 & 0.372 & 0.323 & 0.176 & 0.650 \\
\hline Late fire & -0.74 & $0.022^{*}$ & -0.92 & $0.0004^{* \star *}$ & 0.172 & 0.656 & 0.017 & 0.964 \\
\hline \multicolumn{9}{|l|}{ Water content } \\
\hline Early fire & 0.345 & 0.363 & -0.442 & 0.233 & 0.116 & 0.367 & 0.537 & 0.135 \\
\hline Mid season fire & 0.106 & 0.784 & 0.734 & $0.024^{*}$ & -0.328 & 0.388 & 0.232 & 0.547 \\
\hline Late fire & -0.241 & 0.530 & 0.785 & $0.012^{*}$ & 0.458 & 0.214 & 0.407 & 0.276 \\
\hline
\end{tabular}

$$
\text { * } P<0.05,{ }^{* * *} P<0.001
$$

decreased after the fire application. The same trend was recorded with the mean species richness, except for the mid season fire. Indeed, from a high intensity fire result a low abundance of soil mites. In general, the litter buffers the mineral soil by limiting both the impact of soil compaction and fluctuations in soil temperature and moisture. The removal of soil litter by burn exposes the soil surface directly to the sunlight, and allows evaporating more moisture (Kim and Jung, 2008). Our investigation revealed that one month after the three fire regimes application, the mite density was significantly impacted by the bulk density and soil water content. Thus, the mites emerge in soils rich in water and organic matter (Behan-Pelletier, 1999; Noti et al., 2003). The poverty of Lamto soil in nutrients (Mordelet et al., 1996) consecutive to annual fire application could be due to the low availability of influx of organic matter into the soil because of the depletion of above ground vegetation and depletion of soil surface organic matters by combustion (Kim and Jung, 2008). The high intensity fire $\left(4365 \mathrm{~kW} \cdot \mathrm{m}^{-1}\right)$ caused by a drier vegetation could explain the low density of mites $(1,433 \pm 153$ ind. $\mathrm{m}^{-2}$ ) observed during the mid season fire. In fact, when the vegetation is humid with a green appearance, the fire intensity applied is lower $\left(791 \mathrm{~kW} \cdot \mathrm{m}^{-1}\right)$ and the soil mite density $\left(1,715 \pm 327\right.$ ind. $\left.\mathrm{m}^{-2}\right)$ increases, as recorded during the early fire. In contrast to our expectations, the increase of mite species richness the day after the mid season fire application could be due to vertical variation of the distribution with relatively diverse microhabitats, which might enable the mites to survive better from the flame and fire disturbance (Kim and Jung, 2008). Traditionally, the mid season fire was practiced in Lamto savannah each year for over 30 years. Probably at this time of the year, the species would develop cuticular or genetic adaptations allowing them to resist to flames and fire intensity. However, this latter hypothesis should be studied with a well-established protocol. Whatever the fire regimes, the Simpson diversity index increased after the fire application, showing the emergence of a greater diversity of soil mites after the burning of stands. One of the reasons explaining this variation would be that in addition to specialist species (24 species), over $50 \%$ of the species observed before the burn were rediscovery after the fire application. The comparison with others studies indicates that the densities and species richness observed before the fire application were inferior to those from the works performed by Noti et al. (1996) in a humid savannah of the Democratic Republic of Congo (dry season: 7500 
ind. $\mathrm{m}^{-2}$; rainy season: 13500 ind. $\mathrm{m}^{-2}$; richness: 105 Oribatida species). The research made by Coleman and Rieske (2006) on leaf-litter arthropods and ground-dwelling arthropods in oak-pine forests for two growing seasons following fire disturbance pointed out that burning, including both single and multiple-burns, caused an $83 \%$ reduction in arthropod abundance during the first year and a $48 \%$ reduction in abundance the second year relative to unburned plots. Similarly, their results showed that arthropods richness reduced $20 \%$, and diversity of leaf-litter arthropods increased $15 \%$ in response to prescribed burning relative to unburned plots. However, the work performed by Jacobs et al. (2015) in DuPage County, Illinois indicated that soil mite abundance (5.07 individuals/sample) and diversity indices (0.23) were lower in annually burned plots compared to unburned controls (abundance: 6.28 individuals/sample; diversity: 0.26). Fire is an important variable that causes ecosystem change significantly modifying the structure and functioning of the system (Jung et al., 2010). 41 species had been recorded along the three fire regimes and distributed as follows: early fire 34 species, mid season fire 20 species, late fire 13 species. In fact, changes in vegetation, seasonality and dispersal ability lead to large transformations in composition and functioning of communities of soil animals, triggering specific post-fire successions (Athias-Binche, 1994; Mordkovich et al., 2008; Pérez-Velázquez et al., 2011). As presented in materials and methods section, the early fire was applied in a short-wet season (November) to humid vegetation with a green appearance. The environmental characteristics favorable may accelerate the recolonization by soil mites because of the sufficient energy input. The rever se case is observed across the mid season fire and the late fire, respectively applied in dry season and at the beginning of the rainy season. The inter-annual variation of soil mites showed two trends: (i) the density (early fire, mid season fire, and late fire), mite richness (early fire), and diversity (early fire and late fire) increased, respectively, in the second fire cycle compared to the first one, (ii) mite richness (mid season fire and late fire), and diversity (mid season fire) decreased, respectively, in the second fire cycle compared to the first one. The soil mites respond consistently and predictably to fire. The rebound of soil biological parameters during the second fire cycle could be assigned to litter and woody debris, which burn in a mosaic, reflecting local fire intensity. In addition, this response might have resulted from fire tolerance (Camann et al., 2008). Indeed, from the first fire cycle to the second fire cycle, some species (Afrotrachytes sp.3, Eviphididae sp.1, Gehypotinidae sp.1, Nothrus sp.3, Nothrus sp.4, Oppia sp.1, Oppia sp.3, Damaeidae sp.1, Damaeidae sp.2, Lamellobates sp.1, Scheloribatidae sp.1, Acaronychus sp.1, and Acaridae sp.2) increased numerically during the post-fire recovery period. Jacobs et al. (2015) found an increase of abundance and diversity during the burned plots of October 2009 (abundance: 9.13 individuals/sample; diversity: 0.39) compared to the burned plots of October 2008 (abundance: 7.5 individuals/sample; diversity: 0.29). The works realized by Mordkovich et al. (2008) in the West Siberian plain showed that density (Oribatid mites: 11,000 individuals. $\mathrm{m}^{-2}, 18,000$ individuals. $\mathrm{m}^{-2}$, and 30,000 individuals. $\mathrm{m}^{-2}$; Gamasid mites: 80 individuals. $\mathrm{m}^{-2}, 3,000$ individuals. $\mathrm{m}^{-2}$, and 2,700 individuals. $\mathrm{m}^{-2}$ ) and species richness (Oribatid mites: 15, 28, and 28 species; Gamasid mites: 2, 11, and 11 species) of mites in biotopes of post-fire succession series increase over time, respectively, in the young burnt site, old burnt site, and control plot. However, the decrease of soil biological parameters during the second fire cycle could be due to the decline of Oribatid assemblage heterogeneity in burned stands. The reduction of stand complexity and canopy structure probably diminishes the tolerance of oribatid assemblages for fire disturbance (Camann et al., 2008).

\section{Acknowledgments}

Full thanks to Pr Yéo KOLO, Director of the Lamto Ecology Station, for hosting the project in her institute. We gratefully acknowledge the contributions of Lamto technicians and students for help during the fieldworks. This study was supported by the IRD-Institute Research Development through the JEAI program.

\section{References}

[1] Assié K.H., Angui P. and Tamia A.J. 2008. Effets de la mise en culture et des contraintes naturelles sur quelques propriétés physiques d'un sol ferrallitique au Centre Ouest de la Côte d'Ivoire : Conséquences sur la dégradation des sols. Eur. J. Sci. Res., 23 : 149-166. 
[2] Athias-Binche F. 1994. La phorésie chez les acariens, aspects adaptatifs et évolutifs. CNRS, Laboratoire Arago, Université Paris VI, France.

[3] Badejo M.A. and Ola-Adams B.A. 2000. Abundance and diversity of soil mites of fragmented habitats in a biosphere reserve in southern Nigeria. Pesq. Agropec. Brasilia, 11: 2121-2128.

[4] Balogh J. and Balogh P. 1992. The Oribatid Mites Genera of the World (vol. 1 and 2). The Hungarian National Museum Press, Budapest, Hungary.

[5] Behan-Pelletier V.M. 1999. Oribatid mite biodiversity in agroecosystems: role for bioindication. Agr. Ecosyst. Environ., 74 : 411-423.

[6] Bengtsson J. 2002. Disturbance and resilience in soil animal communities. Euro. J. Soil Biol., 38 : 119-125.

[7] Camann M.A., Gillette N.E., Lamoncha K.L. and Mori S.R. 2008. Response of forest soil Acari to prescribed fire following stand structure manipulation in the southern Cascade Range. Can. J. For. Res., 38 : 956-968.

[8] Camann M.A., Lamoncha K.L. and Gillette N.E. 2012. Oribatid Mite Community Decline Two Years after LowIntensity Burning in the Southern Cascade Range of California, USA. Forests, $3:$ 959-985.

[9] Certini G., Nocentini C., Knicker H., Arfaioli P. and Rumpel C. 2011. Wildfire effects on soil organic matter quantity and quality in two fire-prone Mediterranean pine forests. Geoderma, 167-168: 148-155.

[10] Coleman D.C., Crossley Jr D.A. and Hendrix P.F. 2004. Fundamentals of soil ecology (2nd ed.). Academic Press, Burlington, U.S.A.

[11] Coleman T.W. and Rieske LK. 2006. Arthropod response to prescription burning at the soil-litter interface in oak-pine forests. Forest Ecology and Management, 233: 52-60.

[12] Decaëns T. 2010. Macroecological patterns in soil communities. Glob. Ecol. Biogeogr., 19: 287-302.

[13] Driscoll D.A., Lindenmayer D.B., Bennett A.F., Bode M., Bradstock R.A., Cary G.J., Clarke M.F., Dexter N., Fensham R. and Friend G. 2010. Fire management for biodiversity conservation: Key research questions and our capacity to answer them. Biol. Conserv., 143: 1928-1939.

[14] Gérard G. and Berthet P. 1966. A statistical study of microdistribution of Oribatei (Acari) Part II: The transformation of the data. Oikos, 17: 142-149.

[15] Gulvik M.E. 2007. Mites (Acari) as indicators of soil biodiversity and land use monitoring: A review. Pol. J. Ecol., 55(3): 415-440.

[16] Hudak A.T., Fairbanks D.H.K. and Brockett B.H. 2004. Trends in fire patterns in a southern African savanna under alternative land use practices. Agr. Ecosyst. Environ., 101: 307-325.

[17] Hugo-Coetzee E.A. and Avenant N.L. 2011. The effect of fire on soil oribatid mites (Acari: Oribatida) in a South African grassland. Zoosymposia, 6: 210-220.

[18] Jacobs K.A., Nix B. and Scharenbroch B.C. 2015. The effects of prescribed burning on soil and litter invertebrate diversity and abundance in an Illinois oak woodland. Natural Areas Journal, 35: 318-327.

[19] Jung C., Kim J.W., Marquardt T. and Kaczmarek S. 2010. Species richness of soil gamasid mites (Acari: Mesostigmata) in fire-damaged mountain sites. Journal of Asia-Pacific Entomology, 13: 233-237.

[20] Kim J.W. and Jung C. 2008. Abundance of soil microarthropods associated with forest fire severity in Samcheok, Korea. Journal of Asia-Pacific Entomology, 11: 77-81. 
[21] Kim J.W. and Jung C. 2013. Ecological resilience of soil oribatid mite communities after the fire disturbance. J. Ecol. Environ., 36(2): 117-123.

[22] Krantz G.W. and Walter D.E. 2009. A Manual of Acarology (3 $3^{\text {rd }}$ ed.). Texas Tech University Press, Lubbock, U.S.A.

[23] Menaut J.C. and César J. 1979. Structure and primary productivity of Lamto savannas, Ivory Coast. Ecology, 60(6): 1197-1210.

[24] Mordelet P., Barot S. and Abbadie L. 1996. Root foraging strategies and soil patchiness in a humid savanna. Plant Soil, 182: 171-176.

[25] Mordkovich V.G., Berezina O.G., Lyubechanskii I.I., Andrievskii V.S. and Marchenko I.I. 2008. Soil arthropoda of post-fire successions in northern Taiga of west Siberia. Contemporary Problems of Ecology, 1: 96-103

[26] Murphy B.P., Liedloff A.C. and Cook G.D. 2015. Does fire limit tree biomass in Australian savannas? International Journal of Wildland Fire, 24: 1-13.

[27] N'Dri J.K., N'Da R.A.G., Seka F.A., Pokou P.K., Tondoh J.E., Lagerlöf J., Kone M., Dosso K., N'Dri B.A. and Kone N.A. 2017. Patterns of soil mite diversity in Lamto savannah (Côte d'Ivoire) submitted to different fire regimes. Acarologia, 57: 823-833.

[28] Noti M-I., André H.M., Ducarme X. and Lebrun Ph. 2003. Diversity of soil oribatid mites (Acari: Oribatida) from high Katanga (Democratic Republic of Congo): a multiscale and multifactor approach. Biodiv. Conserv., 12: 767-785.

[29] Noti M-L., André H.M. and Dufrêne M. 1996. Soil oribatid mite communities (Acari: Oribatida) from high Shaba (Zaire) in relation to vegetation. Appl. Soil Ecol., 5: 81-96.

[30] Pérez-Velázquez D., Castaño-Meneses G., Callejas-Chavero A. and Palacios-Vargas J.G. 2011. Mesostigmatid mite (Acari: Mesostigmata) diversity and abundance in two sites in Pedregal de San Ángel Ecological Reserve, Distrito Federal, México. Zoosymposia, 6 : 255-259.

[31] Riou G. 1974. Les sols de la savane de Lamto. Bulletin de Liaison des Chercheurs de Lamto, $1: 3-45$.

[32] Russell-Smith J., Cook G.D., Cooke P.M., Edwards A.C., Lendrum M., Meyer C.P. and Whitehead P.J. 2013. Managing fire regimes in north Australian savannas: applying Aboriginal approaches to contemporary global problems. Front. Ecol. Environ., doi:10.1890/120251.

[33] Soro D.T. 2016. Caractéristiques des régimes de feu et impacts à court terme sur la dynamique de la végétation en savane guinéenne (réserve scientifique de Lamto, Côte d'Ivoire). Mémoire de master 2, Université Nangui Abrogoua, Abidjan, Côte d'Ivoire.

[34] Thioulouse J., Chessel D., Dolédec S. and Olivier J.M. 1997. ADE-4: a multivariate analysis and graphical display software. Stat. Comput., 7: 75-83.

[35] Walter D.E., Latonas S. and Byers K. 2013. Almanac of Alberta Oribatida Part1. Ver. 2.3. The Royal Aberta Museum, Edmonton, AB.

[36] Yang B., Liu X., Ge F., Bao W., Fu S. and Liang W. 2015. Do shifts in soil Oribatida (Acari, Oribatida) give information on differences in fruit yield of Chinese star anise? Agr. Ecosyst. Environ., 207: 211-217.

[37] Yang X. and Chen J. 2009. Plant litter quality influences the contribution of soil fauna to litter decomposition in humid tropical forests, southwestern China. Soil Biol. Biochem., 41: 910-918. 
[38] Zhao J., Shao Y., Wang X., Neher D.A., Xu G., Li Z.A. and Fu S. 2013. Sentinel soil invertebrate taxa as bioindicators for forest management practices. Ecol. Indic., 24: 236-239.

Appendix: List of the mite species with abundance (total from all samples) recorded along the different fire regimes and sampling periods $(n=15)$. BE-Before fire, AF-After fire, OM-One month later. D-Dominance index (species/number ratio expressed in percentages) from each fire regime. With (*): ubiquitous species; without $\left({ }^{\star}\right)$ : specialist's species.

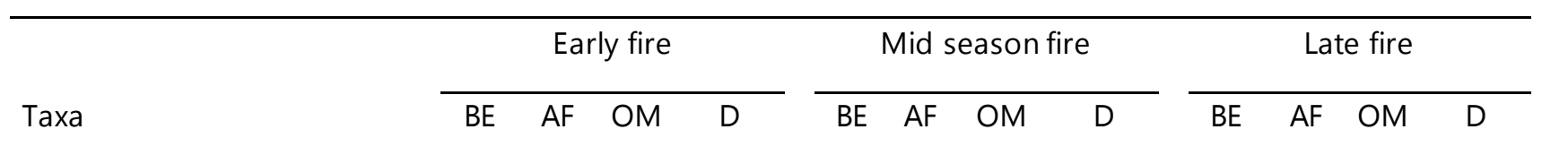

Actinedida

Microtrombidium sp.1

$0 \quad 0$

0.00

$\begin{array}{llll}1 & 1 & 1 & 3.37\end{array}$

$\begin{array}{lll}1 & 2 & 0 \\ 0 & 0 & 3\end{array}$

4.35

$\begin{array}{llll}0 & 0 & 0 & 0.00 \\ 2 & 0 & 0 & 2.74\end{array}$

Cheyletidae sp. $1^{*}$

$\begin{array}{llll}1 & 1 & 1 & 3.37\end{array}$

$\begin{array}{lllll}4.35 & 2 & 0 & 0 & 2.74\end{array}$

Gamasida

Gamasina

Eviphididae sp.1*

Eviphididae sp.3

Laelaptonyssidae sp.1

$4 \quad 1 \quad 0 \quad 5.62$

$\begin{array}{llll}3 & 0 & 0 & 3.3\end{array}$

3.37

$\begin{array}{llll}0 & 0 & 1 & 112\end{array}$

0

2.90

020

2.74

Uropodina

Afrotrachytes sp.1

20

Afrotrachytes sp.3

20

$\begin{array}{lllll}3.37 & 0 & 0 & 0 & 0.00\end{array}$

0

0

0.00

Trachyuropodidae sp.1

$\begin{array}{llll}0 & 0 & 0 & 0.00\end{array}$

0.00

$\begin{array}{llll}0 & 0 & 0 & 0.00\end{array}$

Trachyuropodidae sp.2

$0 \quad 0$

1.12

$\begin{array}{llll}2 & 3 & 0 & 5.62\end{array}$

Trachyuropodidae sp.3

$\begin{array}{llll}2 & 3 & 0 & 5.62 \\ 0 & 0 & 0 & 0.00\end{array}$

00

0.00

020

2.74

Trematuridae sp.1

$\begin{array}{llll}0 & 0 & 0 & 0.00\end{array}$

Uropoda sp.3

10

1.12

0.00

$\begin{array}{llll}0 & 0 & 0 & 0.00\end{array}$

$\begin{array}{llllllll}0 & 0 & 0 & 0.00 & 0 & 0 & 0 & 0.00\end{array}$

Oribatida

Palaeosomata

Acaronychus sp.1*

$\begin{array}{llll}2 & 1 & 0 & 3.37\end{array}$

100

$\begin{array}{lllll}1.45 & 0 & 0 & 0 & 0.00\end{array}$

$\begin{array}{llllllll}0 & 0 & 0 & 0.00 & 0 & 0 & 0 & 0.00\end{array}$

Parhyposomata

Gehypochthoniidae sp.1*

$\begin{array}{llll}0 & 0 & 1 & 1.12\end{array}$

1.12

0

$\begin{array}{lllllll}0 & 1 & 1.45 & 0 & 0 & 0 & 0.00\end{array}$ 


\section{Desmonomata}

Nothrus sp.1*

Nothrus sp.3

$\begin{array}{llll}1 & 1 & 0 & 2.25\end{array}$

$\begin{array}{llll}0 & 0 & 0 & 0.00\end{array}$

$\begin{array}{llll}0 & 0 & 2 & 2.74\end{array}$

Nothrus sp.4

$\begin{array}{llllllll}2 & 3 & 1 & 6.74 & 0 & 0 & 0 & 0.00\end{array}$

$\begin{array}{llll}0 & 0 & 0 & 0.00\end{array}$

Mixonomata

Javacarus sp.1

Phthiracarus sp.1

$\begin{array}{llll}3 & 0 & 0 & 3.37\end{array}$

$\begin{array}{llll}0 & 0 & 0 & 0.00\end{array}$

$\begin{array}{llll}0 & 0 & 0 & 0.00\end{array}$

Brachypylina

Carabodes sp.1

Eremobelba sp.1*

Oppia sp.1*

Oppia sp.2*

Oppia sp.3*

Oppiidae sp.1*

Oppiidae sp. 2

Damaeidae sp.1*

Damaeidae sp.2*

Dolicheremaeus sp.1

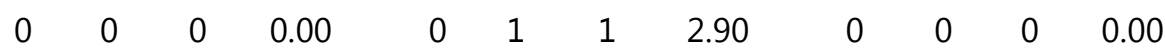
$\begin{array}{llllllllllll}1 & 2 & 0 & 3.37 & 0 & 1 & 0 & 1.45 & 0 & 0 & 0 & 0.00\end{array}$ $\begin{array}{llllllllllll}2 & 1 & 0 & 3.37 & 0 & 0 & 3 & 4.35 & 30 & 4 & 0 & 46.58\end{array}$ $\begin{array}{llllllllllll}0 & 0 & 3 & 3.37 & 0 & 0 & 0 & 0.00 & 0 & 2 & 0 & 2.74\end{array}$ $\begin{array}{llllllllllll}0 & 1 & 0 & 1.12 & 0 & 0 & 1 & 1.45 & 2 & 0 & 6 & 10.96\end{array}$ $\begin{array}{llllllllllll}3 & 0 & 1 & 4.49 & 0 & 2 & 2 & 5.80 & 0 & 0 & 0 & 0.00\end{array}$ $\begin{array}{llllllllllll}1 & 1 & 0 & 2.25 & 0 & 0 & 0 & 0.00 & 0 & 0 & 0 & 0.00\end{array}$ $\begin{array}{llllllllllll}2 & 1 & 1 & 4.49 & 3 & 0 & 1 & 5.80 & 0 & 0 & 0 & 0.00\end{array}$ $\begin{array}{llllllllllll}0 & 0 & 4 & 4.49 & 0 & 2 & 0 & 2.90 & 2 & 5 & 0 & 9.59\end{array}$

Brachypylina, Poronota

Ceratozetidae sp. $3^{*}$

Haplozetidae sp.1

Galumna sp.1*

Galumnella sp.2

Mycobatidae sp.1

Mycobatidae sp.2

Lamellobates sp.1*

Scheloribatidae sp.1*

Scheloribatidae sp.2

Scheloribatidae sp.3

6.74

$\begin{array}{llll}0 & 0 & 0 & 0.00\end{array}$

$\begin{array}{llll}2 & 1 & 1 & 4.49\end{array}$

$\begin{array}{llll}1 & 0 & 0 & 1.12\end{array}$

$\begin{array}{llll}1 & 0 & 0 & 1.12\end{array}$

$0 \quad 0$

$0 \quad 0$

11

$\begin{array}{llll}0 & 0 & 1 & 1.12\end{array}$

$\begin{array}{llll}0 & 0 & 0 & 0.00\end{array}$ $\begin{array}{llll}0 & 2 & 0 & 2.90\end{array}$

$\begin{array}{llll}1 & 0 & 0 & 1.45\end{array}$

1.45

4.35

0.00

0.00

0.00

1.45

13.04

$\begin{array}{llll}0 & 0 & 0 & 0.00\end{array}$

$\begin{array}{llll}0 & 0 & 0 & 0.00\end{array}$ $\begin{array}{llll}0 & 0 & 0 & 0.00\end{array}$ $\begin{array}{llll}2 & 0 & 0 & 2.74\end{array}$ $\begin{array}{llll}0 & 0 & 0 & 0.00\end{array}$ $\begin{array}{llll}2 & 0 & 0 & 2.74\end{array}$ $\begin{array}{llll}0 & 0 & 0 & 0.00\end{array}$ $\begin{array}{llll}0 & 0 & 0 & 0.00\end{array}$ $\begin{array}{llll}0 & 0 & 0 & 0.00\end{array}$ $\begin{array}{llll}0 & 0 & 0 & 0.00\end{array}$ $\begin{array}{llll}0 & 0 & 0 & 0.00\end{array}$ $\begin{array}{llll}0 & 0 & 0 & 0.00\end{array}$ $\begin{array}{llll}0 & 0 & 2 & 2.74\end{array}$ 
Acaridae sp.2

Acaridae $\mathrm{sp} .3^{*}$ $\begin{array}{llllllllllll}0 & 0 & 0 & 0.00 & 21 & 0 & 0 & 30.43 & 0 & 0 & 0 & 0.00\end{array}$

$\begin{array}{llllllllllll}0 & 0 & 2 & 2.25 & 0 & 0 & 4 & 5.80 & 2 & 0 & 4 & 8.22\end{array}$ 